\title{
PENGARUH PENGGUNAAN TEPUNG Lemna sp. TERFERMENTASI PADA PAKAN BUATAN TERHADAP TINGKAT PEMANFAATAN PAKAN, PERTUMBUHAN DAN KELULUSHIDUPAN BENIH IKAN LELE DUMBO (Clarias gariepinus)
}

\author{
Ika Nurul Asriyanti, Johannes Hutabarat, dan Vivi Endar Herawati*1
}

\begin{abstract}
The cost of feed is one of the production costs that account for $65 \%$, so the need for alternative feed ingredients that can reduce feed costs. Lemna plant has good enough nutrition as alternative food such as protein 32,13\%, nitrogen extract (BETN) 15,96\%, and fat 5,13\%, crude fiber 28,58\% and ash 18, 20\% that can be used as fish feed ingredients.The aim of this study is to determine the effect and the best dose level of fermented lemna flour to the level of feed utilization, growth and survival of dumbo catfish (C. gariepinus).The experimental fish used was juvenile of catfishwith an average individual body weight of 3,43 $\pm 0,06 \mathrm{~g}$ and the density of 1 fish/2 l for 42 days. This experimental applied completely randomized design $(C R D)$, which consisted of 5 treatments and 3 replicates. The treatments were treatment each by an addition of flour lemna fermented $0 \%(A), 5 \%(B), 10 \%(C)$, $15 \%(D)$ and $20 \%(E)$ respectively. The results showed that the flour lemna fermented provided significantly effect $(P<0,05)$ on total feed comsumption, feed utilization effeciency), protein efficiency ratio and relative growth rate. However, no significant effects $(P>0,05)$ wereoccured on the values of survival rate. The highest dose of $20 \%$ dose of fermented lemon flour resulted in total feed intake of $170.01 \pm 9.25 \mathrm{~g}$, feed efficiency of $78.82 \pm 4.75 \%$, protein efficiency ratio of $2.49 \pm$ $0.15 \%$ and the relative growth rate (of $4.60 \pm 0.31 \%$ / day, while the optimum dose offermented lemon flour to total feed consumption, the efficiency offeed utilization protein efficiency ratio and relative growth rate have not found the optimum point because based on orthogonal polynomial test still patterned linear.
\end{abstract}

Keywords: catfish (C. gariepinus), flour lemna fermented, feed utilization, growth, survival rate

\section{Pendahuluan}

Ikan lele merupakan jenis ikan air tawar yang mudah dibudidayakan dan jumlah permintaan ikan lele konsumsi tinggi. Menurut KKP (2013), target produksi ikan lele dari tahun 2010 sampai tahun 2013 mengalami peningkatan yaitu dari 242,81 ton menjadi 758,46 ton. Pemenuhan target produksi budidaya ikan lele dapat dicapai salah satunya dengan

\footnotetext{
${ }^{1}$ Departemen Akuakultur, Fakultas Perikanan dan Ilmu Kelautan, Universitas Diponegoro Jl. Prof. Soedarto, SH, Tembalang, Semarang. Jawa Tengah - 50275, Telp/Fax. +6224 7474698
} 
cara budidaya ikan secara intensif. Budidaya intensif meminimalisir ketergantungan terhadap pakan alami, sehingga pakan buatan menjadi satusatunya sumber makanan bagi organisme yang dipelihara (Ekasari, 2009). Pakan buatan meruapkan biaya produksi yang presentasenya cukup tinggi yaitu pada biaya pakan. Menurut Pomeroy et al. (2006), bahwa pakan merupakan salah satu biaya produksi yang menyumbang $65 \%$ dari total biaya produksi, sehingga perlu adanya alternatif bahan pakan yang dapat menekan biaya pakan. Kendala lain yang dihadapi yaitu bungkil kedelai sebagai bahan pakan merupakan bahan baku impor, sehingga perlu dicari alternatif lain yang cukup tersedia dengan kandungan nutrien yang hampir sama dan harga terjangkau (Rismarianty, 2015).

Salah satu bahan yang belum dimanfaatkan adalah lemna yang merupakan salah gulma air yang tidak memiliki nilai jual dan tidak bersaing dengan kebutuhan manusia. Lemna bersifat kosmopolitan atau bisa tumbuh di mana seperti rawa, persawahan, genangan air dan kolam. Ketersediaan dan perkembangannya di alam sangat baik, memiliki kandungan nutrisi seperti protein nabati dan tidak bersaing dengan kebutuhan manusia. Selain itu menurut Crismadha (2015), bahwa laju pertumbuhan lemna yang cepat dan sangat mudah untuk dikembangkan, dimana pertumbuhannya mencapai 40 persen per hari, umur hidupnya sekitar 10 hari dan mampu menghasilkan hingga 20 anakan yang menempel pada induknya. Tingkat produktivitas biomassanya juga cukup tinggi, yaitu
10 ton berat kering per hektar per tahunnya. Biomassa tumbuhan lemna dapat dikeringkan dan disimpan untuk waktu yang relatif lama.Selain itu, lemna mempunyai kandungan protein tinggi, yaitu mencapai $10-43$ $\%$ berat keringnya (Mohaputra dan Putra, 2013; Ilyas, 2014). Oleh karena itu, lemna sangat berpotensi sebagai bahan penyusun pakan ikan sebagai sumber protein nabati pengganti tepung bungkil kedelai.

Berdasarkan hasil uji proksimat, tumbuhan lemna memiliki kandungan nutrisi yang cukup baik seperti protein sebanyak $23,47 \%$,bahan ekstrak tanpa nitrogen (BETN) sebanyak 19,02\%, dan lemak sebanyak 3,99\%, serat kasar 29,92\% dan abu 23,6\% yang dapat digunakan sebagai bahan pakan ikan. Kandungan serat kasar yang tinggi pada lemna akan sulit dicerna oleh tubuh ikan, sehingga untuk menangani masalah tersebut dilakukan fermentasi menggunakan probiotik EM-4. Menurut Revi et al. (2013), fermentasi merupakan cara untuk menurunkan serat kasar dengan cara merombak rantai polimer panjang dari protein menjadi asam amino, lemak menjadi asam lemak esensial, dan karbohidrat menjadi asam gula sederhana, sehingga pakan mudah diserap dan dicerna oleh tubuh ikan.

Penelitian ini bertujuan untuk mengetahui pengaruh penggunaan tepung lemna terfermentasi dan menentukan dosis optimum untuk meningkatkan efisiensi pemanfaatan pakan, pertumbuhan, dan kelulushidupan ikan lele dumbo ( $C$. gariepinus). 


\section{Metode}

Ikan uji yang digunakan dalam penelitian ini adalah benih ikan lele dumbo (C. gariepinus) dengan ratarata bobot awal 3,43 $\pm 0,06$ (Mohapatra dan Patra, 2013). Benih berasal dari hatchery skala rumah tangga (HSRT) yang ada di Siwarak, Ungaran, Semarang. Padat tebar benih untuk tiap perlakuan dan ulangan sebanyak 1 ekor/2 1 air (Yunus et al., 2014). Wadah yang digunakan adalah akuarium berukuran 17 x 39 x $59 \mathrm{~cm}$ dan diisi air sebanyak $50 \%$ dari kapasitas wadah, dilengkapi dengan aerasi untuk mensuplai oksigen dalam air (Madinawati et al., 2011). Tahap pengujian pakan dilakukan selama 42 hari (Sogbesan et al., 2015). Frekuensi pemberian pakan sebanyak 3 kali yaitu pagi, siang, dan sore hari secara at satiation (SNI, 2000). Setiap 3 hari sekali dilakukan penyiponan untuk membuang sisa pakan dan kotoran ikan (Madinawati et al., 2011).

Pakan uji yang digunakan adalah pakan buatan yang dibuat sendiri menggunakan bahan baku lokal yaitu tepung ikan, tepung kedelai, tepung lemna, tepung dedak, tepung terigu, tepung jagung, minyak ikan, minyak jagung, vitamin-mineral, CMC dan air. Tepung lemna dibuat dari tumbuhan lemna yang diambil dari perairan yang kemudian dilakukan pencucian, pengeringan, penepungan, dan difermentasi menggunakan probiotik $\mathrm{EM}_{4}$ sebanyak $1 \mathrm{ml}$ dan molase sebagai aktifator dengan perbandingan 1:1 kedalam $100 \mathrm{ml}$ air dan didiamkan selama \pm 3 jam (Zahidah et al., 2012; Yuniwati et al., 2012; Warasto et al., 2013). Fermentasi tepung lemna dilakukan dengan cara mencampurkan fermentor dengan tepung lemna secara merata. Perbandingan pencampuran antara larutan (satuan $\mathrm{ml}$ ) dan tepung lemna (satuan g) yaitu 3:10 (Warasto et al., 2013). Hasil pencampuran selanjutnya dimasukkan dalam kantong plastik dan disimpan pada suhu $29^{\circ} \mathrm{C}$ selama tujuh hari. Hasil dari fermentasi tepung lemna ditunjukkan dengan bau asam khas fermentasi, tahap selanjutnya tepung lemna dibuka dan dikeringanginkan dan diuji proksimat untuk menentukan formulasi pakan.

Proses penentuan formulasi pakan dalam pembuatan pakan uji didasarkan pada kebutuhan protein dari ikan uji, dimana kebutuhan protein dari ikan lele dumbo yaitu 25$30 \%$ (SNI, 2006). Pembuatan pakan diawali dengan pencampuran bahan pakan dari jumlah yang terkecil sampai yang terbesar dan diaduk hingga homogen, kemudian ditambahkan air hangat sebanyak 35$40 \%$ dari total bahan. Penambahan air dilakukan sambil bahan diaduk sampai merata dan kalis, sehingga bisa dibuat gumpalan-gumpalan untuk dicetak menggunakan gilingan dan dikeringkan menggunakan oven dengan suhu $<50{ }^{0} \mathrm{C}$, sampai kadar air pakan konstan. Pakan yang sudah kering dilakukan analisa proksimat. Komposisi pakan yang digunakan dalam penelitian tersaji pada Tabel 1 . 
Tabel 1. Komposisi dan analisa proksimat pakan yang digunakan selama penelitian (\% bobot kering)

\begin{tabular}{lccccc}
\hline \multicolumn{5}{c}{ Jenis Bahan } & \multicolumn{5}{c}{ Pakan $(\mathbf{g})$} \\
\cline { 2 - 6 } Penyusun Pakan & $\mathbf{A}$ & $\mathbf{B}$ & $\mathbf{C}$ & $\mathbf{D}$ & $\mathbf{E}$ \\
\hline Tp. Ikan & 51,09 & 50,85 & 50,61 & 50,37 & 50,12 \\
Tp. Bkl. Kedelai & 18,32 & 14,53 & 10,79 & 7,08 & 3,39 \\
Tp. Lemna & 0,00 & 5,52 & 10,98 & 16,39 & 21,74 \\
Tp. Terigu & 10,13 & 8,07 & 4,91 & 3,60 & 1,99 \\
Tp. Dedak & 4,54 & 10,06 & 12,40 & 13,72 & 14,44 \\
Tp. Jagung & 7,95 & 3,04 & 2,42 & 1,00 & 0,50 \\
Minyak Ikan & 1,77 & 1,76 & 1,75 & 1,74 & 1,74 \\
Minyak Jagung & 0,88 & 0,88 & 0,88 & 0,87 & 0,87 \\
Vit-Min mix & 4,42 & 4,40 & 4,38 & 4,36 & 4,34 \\
CMC & 0,88 & 0,88 & 0,88 & 0,87 & 0,87 \\
\hline TOTAL (\%) & $\mathbf{1 0 0 , 0 0}$ & $\mathbf{1 0 0 , 0 0}$ & $\mathbf{1 0 0 , 0 0}$ & $\mathbf{1 0 0 , 0 0}$ & $\mathbf{1 0 0 , 0 0}$ \\
\hline \multicolumn{1}{c}{ Hasil analisa proksimat pakan (\% bobot kering) } \\
\hline Protein (\%) & 32,40 & 32,04 & 32,66 & 32,03 & 31,73 \\
BETN (\%) & 17,44 & 17,20 & 13,61 & 15,14 & 12,66 \\
Lemak (\%) & 7,31 & 7,74 & 9,96 & 10,78 & 11,35 \\
En. (kkal)* & 256,01 & 249,07 & 244,13 & 239,67 & 235,60 \\
Rasio E/P** & 8,53 & 8,30 & 8,16 & 8,04 & 7,93 \\
\hline
\end{tabular}

* Berdasarkan perhitungan DE (digestable energy) dengan asumsi untuk persamaan energi (NRC, 1988), yaitu $1 \mathrm{~g}$ karbohidrat $=2.5 \mathrm{kkal} \mathrm{DE}, 1 \mathrm{~g}$ protein $=3.5 \mathrm{kkal} \mathrm{DE}$, dan $1 \mathrm{~g}$ lemak $=8.1 \mathrm{kkal} \mathrm{DE}$. ** Menurut De Silva (1987), nilai E/P bagi pertumbuhan optimal ikan berkisar antara $8-12 \mathrm{kkal} / \mathrm{g}$

Penelitian ini dilakukan dengan metode eksperimental dan rancangan percobaan yang digunakan yaitu Rancangan Acak Lengkap (RAL) dengan 5 perlakukan dan 3 kali ulangan sehingga diperlukan 15 unit percobaan. Perlakuan yang digunakan yaitu perbedaan persentase penambahan tepung lemna terfermentasi dalam formulasi pakan. Adapun perlakuan dalam penelitian ini berdasarkan menurut Mohapatra dan Patra (2013), adalah sebagai berikut:

$$
\begin{array}{rlr}
\mathrm{A}= & 0 \% \quad \text { tepung } & \text { lemna } \\
& \text { terfermentasi } & \text { dalam } \\
& \text { formulasi pakan } & \\
\mathrm{B}= & 5 \% \text { tepung } & \text { lemna } \\
& \text { terfermentasi } & \text { dalam } \\
& \text { formulasi pakan } &
\end{array}
$$

$$
\begin{array}{rlr}
\mathrm{C}= & 10 \% \text { tepung } & \text { lemna } \\
& \text { terfermentasi } & \text { dalam } \\
& \text { formulasi pakan } & \\
\mathrm{D}= & 15 \% \quad \text { tepung } & \text { lemna } \\
& \text { terfermentasi } & \text { dalam } \\
& \text { formulasi pakan } &
\end{array}
$$$$
\mathrm{E}=20 \% \text { tepung lemna }
$$
terfermentasi dalam formulasi pakan

Dasar penentuan dosis penggunaan tepung lemna terfermentasi didasarkan pada penelitian Mohapatra dan Patra (2013) dengan dosis terbaik adalah $15 \%$.

Pengumpulan data meliputi nilai total konsumsi pakan (TKP), efisiensi pemanfaatan pakan (EPP), protein efficiency ratio PER), laju pertumbuhan relatif (RGR) dan kelulushidupan (SR). Data kualitas air 
yang diukur meliputi DO, $\mathrm{pH}$, suhu, dan amonia.

\section{Total Konsumsi Pakan}

Total konsumsi pakan dihitung dengan menggunakan rumus Pereira et al. (2007) sebagai berikut:

$$
T K P=F 1+F 2+\ldots .+F n
$$

Keterangan:

TKP $=$ Total konsumsi pakan

F1 = Jumlah pakan hari pertama (g)

F2 = Jumlah pakan hari kedua $(\mathrm{g})$

Fn = Jumlah pakan hari ke-n $(\mathrm{g})$

\section{Efisiensi Pemanfaatan Pakan}

Nilai efisiensi pemanfaatan pakan (EPP) dapat ditentukan dengan rumus Tacon (1987) sebagai berikut:

$$
E P P=\frac{W t-W 0}{F} \times 100 \%
$$

Keterangan:

$\mathrm{EPP}=$ Efisiensi pemanfaatan pakan $(\%)$

$\mathrm{W}_{\mathrm{t}}=$ Bobot total ikan pada akhir penelitian $(\mathrm{g})$

$\mathrm{W}_{\mathrm{o}}=$ Bobot total ikan pada awal penelitian (g)

$\mathrm{F} \quad=$ Jumlah pakan yang dikonsumsi selama penelitian $(\mathrm{g})$

\section{Protein Efisiensi Rasio}

Nilai protein efisiensi rasio (PER) dapat ditentukan dengan menggunakan rumus Sogbesan et al. (2015) sebagai berikut:

$$
P E R=\frac{W t-W 0}{P i} \times 100 \%
$$

Keterangan:

PER $=$ Protein efisiensi rasio $(\%)$

$\mathrm{W}_{\mathrm{t}}=$ Bobot total ikan pada akhir penelitian $(\mathrm{g})$

$\mathrm{W}_{\mathrm{o}}=$ Bobot total ikan pada awal penelitian $(\mathrm{g})$

$\mathrm{Pi}=$ Jumlah pakan yang dikonsumsi $\mathrm{x} \%$ protein pakan

\section{Laju Pertumbuhan Relatif}

Menurut Sogbesan et al. (2015), laju pertumbuhan relatif atau relative growth rate (RGR) ikan dihitung menggunakan rumus sebagai berikut:

$$
R G R=\frac{W t-W 0}{W 0 \times W t} \times 100 \%
$$

Keterangan:

$\mathrm{RGR}=$ Laju pertumbuhan relatif $(\%$ per hari)

$\mathrm{W}_{\mathrm{t}}=$ Bobot total ikan pada akhir pemeliharaan $(\mathrm{g})$

$\mathrm{W}_{\mathrm{o}}=$ Bobot total ikan pada awal pemeliharaan $(\mathrm{g})$

$\mathrm{t}=$ Waktu pemeliharaan (hari)

\section{Kelulushidupan}

Kelulushidupan atau survival rate (SR) dihitung untuk mengetahui tingkat kematian kematian ikan uji selama penelitian, kelulushidupan dapat dihitung berdasarkan rumus Effendi (1997):

$$
S R=\frac{N t}{N 0} \times 100 \%
$$

Keterangan:

SR = Tingkat kelulushidupan ikan

(\%) 


$$
\begin{aligned}
\mathrm{N}_{\mathrm{t}}= & \text { Jumlah ikan pada akhir } \\
& \text { penelitian (ekor) } \\
\mathrm{N}_{0}= & \begin{array}{l}
\text { Jumlah ikan pada awal } \\
\text { penelitian (ekor) }
\end{array}
\end{aligned}
$$

\section{Parameter Kualitas Air}

Parameter data kualitas air yang diukur meliputi DO, $\mathrm{pH}$, suhu, amonia. DO diukur dengan menggunakan $\mathrm{DO}$ meter, $\mathrm{pH}$ diukur dengan $\mathrm{pH}$ meter, suhu diukur dengan termometer dan untuk pengukuran amonia, sampel air diukur di laboratorium teknik lingkungan, UNDIP.

\section{Analisis Data}

Data yang berbentuk persentase meliputi efisiensi pemanfaatan pakan (EPP), protein efficiency rasio (PER), laju pertumbuhan relative (RGR) dan kelulushidupan (SR) yang diperoleh harus dilakukan transformasi data terlebih dahulu. Hal ini sesuai dengan pernyataan Hanafiah (2000); Steel dan Torrie (1989), bahwa data yang berbentuk persen dan berkisar antara $0-30 \%$ atau $70-100 \%$ perlu dilakukan transformasi arcsin terlebih dahulu selanjutnya baru dilakukan uji normalitas, uji homogenitas, dan uji additivitas guna memastikan bahwa data bersifat normal, homogen dan aditif. Data kemudian dianalisis ragam (uji F) pada taraf kepercayaan 95\% untuk melihat pengaruhnya. Srigandono (1992) mengemukakan bahwa bila dalam analisis ragam diperoleh beda nyata $(\mathrm{P}<0,05 \%)$, maka dilakukan uji wilayah ganda Duncan. Data kualitas air dianalisis secara deskriptif.

\section{Hasil dan Pembahasan}

Hasil penelitian pengaruh
penggunaan tepung $\begin{array}{r}\text { lemna } \\ \text { terfermentasi pada pakan buatan }\end{array}$
terhadap pemanfaatan pakan meliputi
nilai TKP, EPP, PER; RGR; dan SR.
Berdasarkan data total konsumsi
pakan, efisiensi pemanfaatan pakan,
protein efisiensi rasio, laju
pertumbuhan relatif dan
kelulushidupan pada ikan lele dumbo
(C. gariepinus) selama pemeiharaan
dapat dibuat histogram pada Gambar
1,2,3, 4, dan 5.

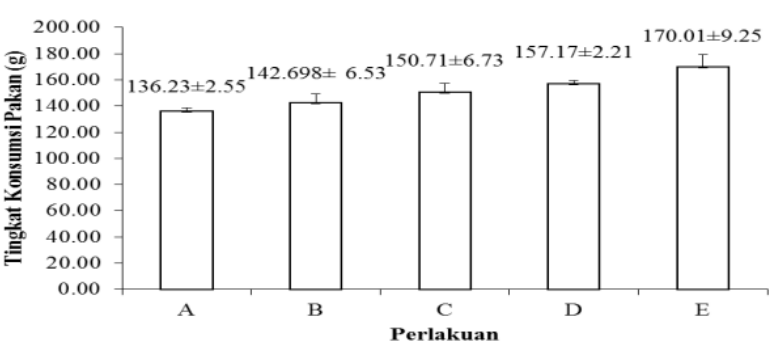

Gambar 1. Nilai Total Konsumsi Pakan Ikan Lele Dumbo (C. gariepinus)

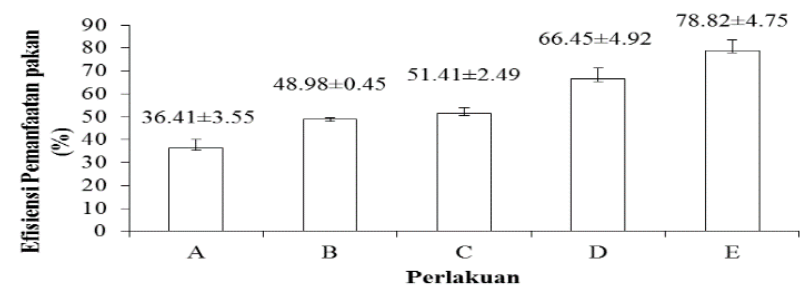

Gambar 2. Nilai Efisiensi Pemanfaatan Pakan Ikan Lele $(C$. gariepinus)

Berdasarkan hasil penelitian bahwa nilai tertinggi rata-rata TKP dan EPP pada perlakuan dosis $20 \%$ (E) sebesar 170,01 $\pm 9,25 \mathrm{~g}$; dan $78,82 \pm 4,75$ sedangkan nilai rata-rata TKP dan EPP terendah pada 
perlakuan dosis $0 \%$ (A) sebesar $136,23 \pm 2,55 \mathrm{~g}$; dan $36,41 \pm 3,55 \%$.

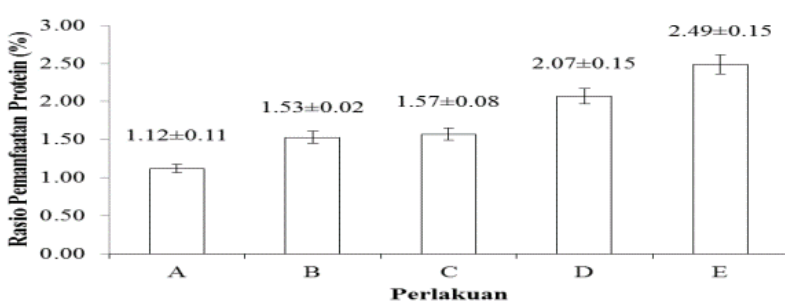

Gambar 3. Nilai Rasio Pemanfaatan Protein Ikan Lele (C. gariepinus)

Berdasarkan hasil penelitian nilai rata-rata PER tertinggi pada perlakuan dosis $20 \%$ (E) yaitu sebesar $2,49 \pm 0,15 \%$; sedangkan nilai rata-rata PER terendah yaitu pada perlakuan dosis $0 \%$ (A) sebesar $1,12 \pm 0,11 \%$.

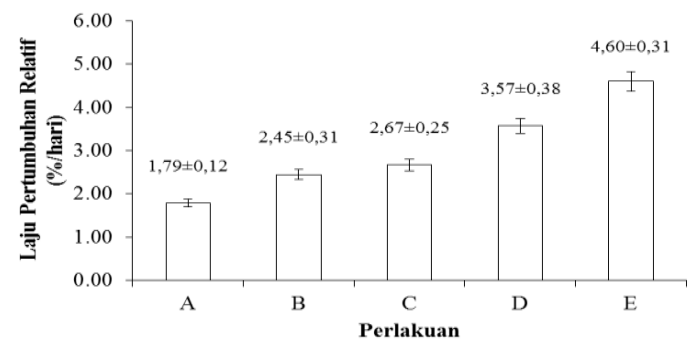

Gambar 4. Nilai Laju Pertumbuhan Relatif Ikan Lele (C. gariepinus)

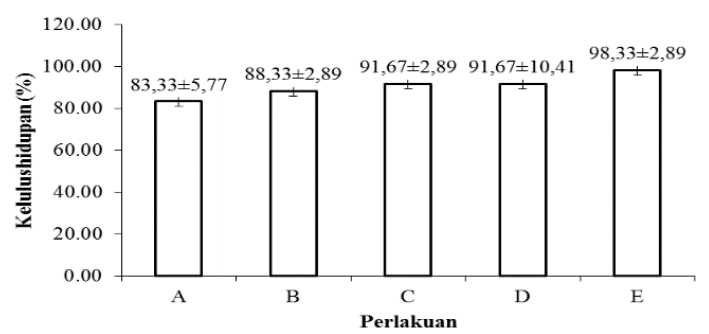

Gambar 5. Nilai Kelulushidupan Ikan Lele (C. gariepinus)

Berdasarkan hasil penelitian nilai rata-rata RGR dan SR yang tertinggi pada perlakuan dosis $20 \%$ (E) sebesar $4,60 \pm 0,31 \%$ /hari dan $98,33 \pm 2,89 \%$, sedangkan nilai rata-rata RGR dan SR yang terendah yaitu pada perlakuan dosis $\quad 0 \% \quad$ (A) sebesar $1,79 \pm 0,12 \%$ /hari; dan $83,33 \pm 5,77 \%$.

Hasil analisis ragam menunjukan bahwa penggunaan tepung lemna terfermentasi pada pakan buatan memberikan pengaruh yang nyata $(\mathrm{P}<0,05)$ terhadap nilai TKP, EPP, PER dan RGR namun tidak berpengaruh nyata $(\mathrm{P}>0,05)$ terhadap nilai SR, untuk mengetahui dosis optimal maka dilakukan uji polinomial orthogonal. Hasil uji polinomial ortogonal disajikan pada Gambar 6, 7, 8, dan 9.

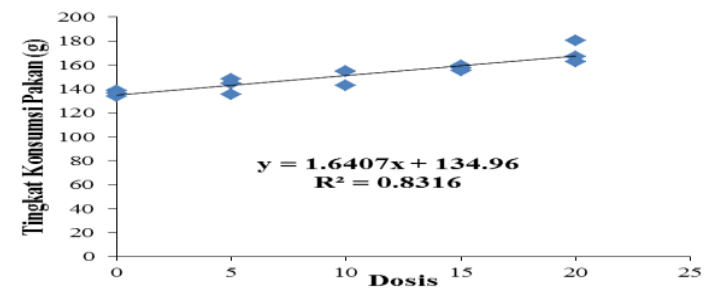

Gambar 6. Polinomial Ortogonal Total Konsumsi Pakan

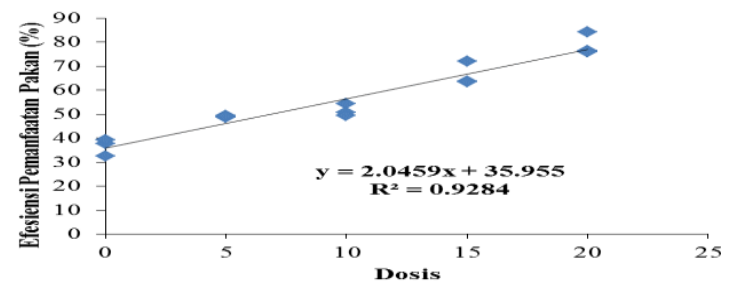

Gambar 7. Polinomial Ortogonal Efisiensi Pemanfaatan Pakan

Berdasarkan hasil uji Polinomial Ortogonal pada TKP diperoleh hubungan yang berpola linier $(\mathrm{y}=$ $1,6407 x+134,96), R^{2}=0,8316$. Nilai $\mathrm{R}^{2}$ menunjukkan bahwa $83,16 \%$ TKP dipengaruhi oleh penggunaan tepung lemna terfermentasi dalam pakan buatan dan 16,84\% dipengaruhi oleh faktor lainnya.

Hasil uji polinomial ortogonal pada EPP diperoleh hubungan yang berpola linier $(y=2,0459 x+35,955)$, $\mathrm{R}^{2}=0,9284$. Nilai $\mathrm{R}^{2}$ menunjukkan 
bahwa 92,84\% EPP dipengaruhi oleh penggunaan tepung lemna terfermentasi dalam pakan buatan dan $7,16 \%$ dipengaruhi oleh faktor lainnya.

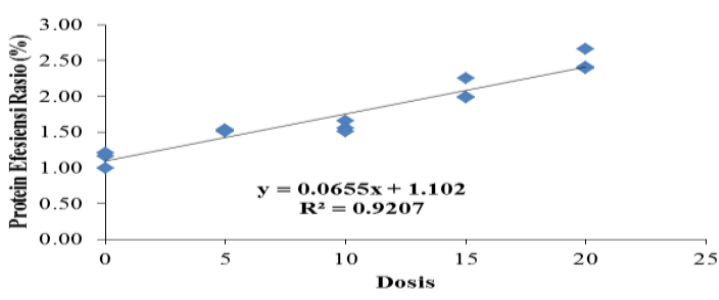

Gambar 8. Polinomial Ortogonal Efisiensi Protein Rasio

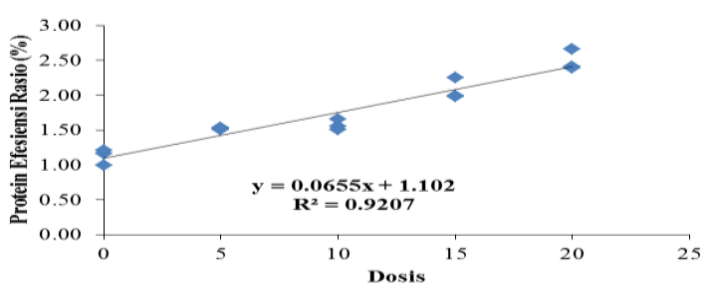

Gambar 9. Polinomial Ortogonal Efisiensi Protein Rasio

Berdasarkan Uji Polinomial Ortogonal pada PER diperoleh hubungan yang berpola linier $(\mathrm{y}=$ $0,0655 x+1,102), R^{2}=0,9207$. Nilai $\mathrm{R}^{2}$ menunjukkan bahwa $92,07 \%$ nilai PER dipengaruhi oleh penggunaan tepung lemna terfermentasi dalam pakan buatan dan $7,93 \%$ dipengaruhi oleh faktor lainnya.

Hasil uji Polinomial Ortogonal pada RGR diperoleh hubungan yang berpola linier $(y=0,1347 x+1,6667)$, $R^{2}=0,9017$. Nilai $R^{2}$ menunjukkan bahwa 90,17\% RGR dipengaruhi oleh penggunaan tepung lemna terfermentasi dalam pakan buatan dan 9,83\% dipengaruhi oleh faktor lainnya.

Hasil pengukuran parameter kualitas air pada media ikan lele dumbo (C. gariepinus) selama pemeliharaan sudah optimal dan sesuai kebutuhan ikan lele (Tabel 2).

Tabel 2. Parameter Kualitas Air selama Pemeliharaan

\begin{tabular}{|c|c|c|}
\hline $\begin{array}{c}\text { Parameter } \\
\text { Kualitas } \\
\text { Air }\end{array}$ & $\begin{array}{c}\text { Kisaran Nilai } \\
\text { Parameter } \\
\text { Kualitas Air }\end{array}$ & $\begin{array}{c}\text { Pustaka } \\
\text { (Kelayakan) }\end{array}$ \\
\hline Suhu $\left({ }^{\circ} \mathrm{C}\right)$ & $25-29$ & $22-34^{a}$ \\
\hline $\mathrm{pH}$ & $6,1-7,5$ & $6,0-9,0^{\mathrm{a}}$ \\
\hline $\mathrm{DO}(\mathrm{mg} / \mathrm{l})$ & $3,00-3,90$ & $\geq 3^{\mathrm{a}}$ \\
\hline $\mathrm{NH}_{3}(\mathrm{mg} / \mathrm{l})$ & $0,0031-0,3037$ & $<1^{\mathrm{b}}$ \\
\hline
\end{tabular}

\section{Pemanfaatan Pakan}

Berdasarkan hasil penelitian perlakuan penambahan tepung Lemna terfermentasi dalam pakan buatan dengan dosis $20 \%$ (E) menghasilkan tingkat konsumsi pakan ikan lele dumbo (C.gariepinus) lebih tinggi yaitu $170,01 \pm 9,25$ g. Hal ini diduga karena pakan yang dibuat pada dosis $20 \%$ memiliki bau yang lebih khas karena ada penambahan tingkat dosis tepung lemna yang difermentasi dengan probiotik, selain itu warna pakan lebih coklat (gelap) yang lebih disukai oleh ikan lele dumbo ( $C$. gariepinus). Hal ini didukung oleh Pamungkas (2013), dan Abidin et al. (2015), bahwa perbedaan tingkat konsumsi pakan dapat dipengaruhi oleh kandungan pada pakan serta palatabilitas pakan yang ditentukan oleh rasa, bau dan warna yang merupakan faktor fisik dan kimia pakan.

Tingkat konsumsi pakan ikan lele dumbo (C. gariepinus) terendah pada perlakuan dosis $0 \%$ (A) yaitu $136,23 \pm 2,55$ g. Pakan buatan perlakuan ini tidak ditambah dengan lemna yang difermentasi dengan probiotik, sehingga bau pakan kurang dideteksi oleh ikan lele dumbo $(C$. 
gariepinus). Hasil penelitian sesuai pernyataan Noviana et al. (2014), bahwa pakan yang diberi perlakuan probiotik lebih menarik aromanya dibandingkan dengan pakan yang tidak diberi perlakuan probiotik. Probiotik yang digunakan untuk memfermentasi tepung lemna mampu menghasilkan bau (aktraktan) dan cita rasa yang khas pada pakan yang dihasilkan, sehingga merangsang ikan untuk mendekati dan mengkonsumsi pakan yang diberikan.

Nilai EPP tertinggi pada perlakuan yang ditambahkan dengan tepung lemna fermentasi dengan dosis 20\% (perlakuan E) yaitu $62,70 \% \pm 3,43$, diduga karena adanya proses fermentasi yang dilakukan pada tepung lemna yang menyebabkan bakteri atau yeast masih aktif sehingga pakan buatan yang mengandung tepung lemna hasil fermentasi akan mengalami perombakan dari senyawa kompleks menjadi senyawa sederhana. Proses penguraian bakteri dan yeast kemungkinan membuat pakan buatan dapat dimanfaatkan oleh tubuh ikan secara efisien dan efektif untuk pertumbuhan. Fadri et al. (2016) menyatakan bahwa probiotik terdapat berbagai mikroorganisme yang bermanfaat, yaitu Laktobacillus yang bermanfaat untuk memfermentasi bahan organik menjadi senyawa asam laktat, bakteri fotosintesis yang berfungsi menyerap gas-gas beracun dan panas dari proses fermentasi, ragi (yeast) yang mempunyai peran dalam memfermentasi bahan organik menjadi senyawa alkohol, gula dan asam amino dan actinomycetes yang berfungsi untuk menghasilkan senyawa antibiotik yang bersifat toksik terhadap bakteri pathogen dan mampu melarutkan ion-ion fosfat dan ion-ion mikro lainnya. Warasto et al. (2013) dalam penelitiannya menyatakan protein tepung gulma air (kiambang) terfermentasi dalam pakan dipecah menjadi asam-asam amino yang lebih mudah diserap ikan sehingga kebutuhan nutriennya akan terpenuhi. Menurut Ananda et al. (2015) pakan ikan akan dikatakan baik apabila nilai efisiensinya lebih dari $50 \%$.

Nilai efisiensi pemanfaatan pakan pada ikan lele dumbo (C.gariepinus) terendah pada perlakuan dosis $0 \%$ yaitu $37,10 \pm 2,12 \%$. Pakan dengan dosis $0 \%$ tepung lemna terfermentasi (A) dan penggunaan $100 \%$ tepung bungkil kedelai diduga pakan lebih sulit untuk dicerna dan dimanfaatkan oleh tubuh ikan lele dumbo ( $C$. gariepinus). Tidak adanya proses fermentasi yang dilakukan pada bahan baku, sehingga pakan buatan yang dihasilkan tidak mengalami penguraian atau perombakan senyawa kompleks menjadi senyawa sederhana, sehingga efesiensi pemanfaatan pakan lebih renadah. Arief et al. (2014) menyatakan bahwa efisiensi pakan yang rendah dipengaruhi aktivitas pencernaan yang tidak dibantu oleh adanya bakteri probiotik sehingga kurangnya penyerapan energi pada pakan untuk pertumbuhan ikan juga kurang sempurna. Menurut Greiner dan Konietzny (2011), asam fitat dapat menurunkan aktifitas enzim dalam saluran pencernaan, menurunkan kelarutan protein, serta menurunkan kecernaan protein. Mengakibatkan tidak adanya proses fermentasi pada pakan dosis 0\% (A), mengakibatkan 
asam fitat pada pakan tidak dapat dihilangkan.

Protein eficiency rasio (PER) merupakan nilai yang menunjukkan jumlah bobot ikan yang dihasilkan dari tiap unit berat protein dalam pakan dengan asumsi bahwa semua protein digunakan untuk pertumbuhan. Berdasarkan hasil penelitian nilai protein efisiensi rasio pemberian pakan dengan penambahan tepung lemna terfermentasi tertinggi pada dosis $20 \%$ (E) yaitu sebesar $2,49 \pm 0,15 \%$. Berdasarkan uji proksimat, kandungan protein pakan yang dibuat memiliki kandungan protein yang hampir sama yaitu 32\%, namun adanya perbedaan laju pertumbuhan relatif pada masing-masing perlakuan. Kandungan asam amino essensial pada perlakuan E memiliki kualitas yang sesuai dengan kebutuhan ikan lele, sehingga protein efisiensi rasionya lebih tinggi. Menurut Dewanji (1993), lemna mengandung asam amino essensial lisin sekitar 6,37\% dan methionine sebanyak $1,72 \%$. Menurut Trisnawati et al. (2014), kebutuhan lisin dan methionin untuk ikan lele yaitu $1,63 \%$ dan $0,74 \%$. Berdasarkan hal tersebut kebutuhan asam amino essensial pada pakan E lebih bagus kualitasnya, sehingga PER perlakuan E lebih tinggi. Asam amino essensial sangatlah penting bagi tubuh ikan khususnya lisin dan methionin yang berfungsi untuk pertumbuhan dan pembetukan tulang ikan lele.

Nilai PER terendah didapat pada perlakuan tanpa pemberian tepung lemna dengan dosis $0 \%$ (A) sebesar $1,12 \pm 0,11 \%$. Nilai pemanfaatan protein menurun seiring dengan pengurangan kadar substitusi tepung lemna terefermentasi pada pakan. Hal ini diperkuat oleh Yilmas et al. (2004), bahwa pemanfaatan protein dan pertumbuhan menurun seiring pengurangan kadar substitusi lemna minor pada pakan. Kualitas protein lemna yang lebih bagus dibandingkan dengan tepung bungkil kedelai. Menurut Francis et al. (2001) sumber nutrisi seperti bungkil kedelai, tepung daun leucaena, dan wijen mengandung berbagai zat antinutritional. Pakan yang menggunakan sumber protein nabati dari tepung bungkil kedelai $100 \%$ (A) memiliki zat antinutrisi yang lebih tinggi dibanding pakan pada perlakuan lainnya, sehingga pakan sulit untuk diserap nutrisinya oleh tubuh ikan. Kemampuan ikan dalam mencerna protein dalam pakan akan berpengaruh terhadap nilai rasio efisiensi protein, sehingga dibutuhkan pakan dengan nutrisi berkualitas dan berkuantitas sesuai dengan kebutuhan ikan agar terjadi pertumbuhan yang maksimal.

\section{Laju Pertumbuhan Relatih}

Laju pertumbuhan ikan sangat bervariasi, tergantung dari faktor internal maupun faktor eksternal. Pertumbuhan ikan akan terjadi apabila ikan mengalami penambahan panjang atau bobot tubuh ikan dalam waktu tertentu. Selain itu pakan yang memiliki kualitas dan kuantitas yang baik juga berpengaruh terhadap pertumbuhan ikan lele. Pertumbuhan yang diamati adalah hasil pengamatan laju pertumbuhan relatif Berdasarkan hasil analisa ragam menunjukkan bahwa penambahan tepung lemna terfermentasi berpengaruh nyata terhadap laju pertumbuhan relatif ikan lele (C. gariepinus). Hasil laju 
pertumbuhan relatif tertinggi terdapat pada penambahan tepung lemna terfermentasi dengan dosis $20 \%$ (E) dalam pakan yaitu $4,60 \pm 0,31 \%$ /hari. Nilai laju pertumbuhan tertinggi pada perlakuan E ini diduga karena kualitas kandungan protein pakan dosis $20 \%$ (perlakuan E) lebih baik dibandingkan pakan lainnya. Menurut Abidin et al. (2015), meskipun nilai kandungan protein dalam pakan tinggi, namun pertumbuhannya rendah hal ini dikarenakan kualitas protein pakan tersebut tidak sesuai dengan kebutuhan ikan.

Selain itu proses fermentasi menggunakan probiotik pada tepung lemna kemungkinan masih ada beberapa bakteri, jamur atau yeast yang masih aktif, sehingga pakan yang dibuat dengan penambahan tepung lemna dosis 20\% (E) lebih mudah untuk dicerna dan dimanfaatkan oleh tubuh ikan untuk pertumbuhan. Menurut Fadri et al. (2016), probiotik terdapat berbagai mikroorganisme yang bermanfaat, yaitu Laktobacillus yang bermanfaat untuk memfermentasi bahan organik menjadi senyawa asam laktat, bakteri fotosintesis yang berfungsi menyerap gas-gas beracun dan panas dari proses fermentasi, ragi (yeast) yang mempunyai peran dalam memfermentasi bahan organik menjadi senyawa alkohol, gula dan asam amino dan actinomycetes yang berfungsi untuk menghasilkan senyawa antibiotik yang bersifat toksik terhadap bakteri pathogen dan mampu melarutkan ion-ion fosfat dan ion-ion mikro lainnya. Menurut Patra (2005), penggunaan 30\% pakan daun Lemna yang difermentasi menunjukkan pertumbuhan ikan mas (Labeo rohita) lebih efisien dalam menghemat biaya dibanding tanpa mengunakan daun lemna yang difermentasi.

\section{Kelulushidupan}

Tingkat kelulushidupan ikan lele tertinggi pada dosis $20 \%$ (E) yaitu 98,33\% dan terendah pada perlakuan dosis $0 \%$ (A) yaitu yaitu $83,33 \%$. Penggunaan tepung lemna terfermentasi dengan dosis tertinggi menghasilakan nilai kelulushidupan yang tinggi juga. Sulawesty et al. (2014), menyatakan bahwa perlakuan ikan mas (Cyprinus carpio L.) yang diberi pakan lemna menghasilkan SR sebesar $70 \%$, sedangkan ikan yang diberi pakan kontrol (tanpa lemna) kelangsunganhidupnya sebesar $60 \%$. Selama pemeliharaan terjadi kematian beberapa ekor ikan pada seluruh perlakuan, kematian ikan lebih banyak terjadi pada hari pertama hingga hari kesepuluh pemeliharaan hal ini diduga karena stres selama pemeliharaan. Menurut Fadri et al. (2016), kematian ikan dapat disebabkan oleh faktor dalam seperti umur dan kemampuan ikan dalam menyesuaikan diri dengan lingkungan, dan faktor luar terdiri dari kondisi abiotik, kompetisi antara spesies, penambahan populasi ikan dalam ruang gerak yang sama, meningkatnya predator dan parasit, kekurangan makanan dan sifat-sifat biologis lainnya terutama yang berhubungan dengan penanganan dan penangkapan.

\section{Kualitas Air}

Berdasarkan kualitas air yang telah diamati selama pemeliharaan ikan lele selama 42 hari, kualitas air yang digunakan sudah optimal dan sesuai dengan kebutuhan ikan lele 
dumbo (C. gariepinus). Nilai pada suhu dan oksigen terlarut perlakuan selama pemeliharaan berkisar 25$29^{\circ} \mathrm{C}$ dan 3,00-3,90 mg/l. Nilai variabel tesebut sudah sesuai untuk budidaya ikan lele. Hal ini didukung oleh pendapat Martudi dan Lilisti (2011), bahwa kualitas air yang dianggap baik untuk kehidupan lele adalah suhu untuk pemeliharaan 22$34{ }^{\circ} \mathrm{C}$ dan oksigen terlarut $>3 \mathrm{mg} / \mathrm{l}$. Nilai $\mathrm{pH}$ yang diperoleh pada saat penelitian yaitu 6,1-7,5; hasil dari variabel tersebut masih dalam batas kelayakan. Hal ini didukung oleh Madinawati (2011), bahwa ikan lele dapat hidup pada kisaran pH 6,5-8. Hasil pengukuran amonia yang didapatkan sebesar 0,0031-0,3037 $\mathrm{mg} / \mathrm{l}$, yang dikategorikan masih dalam kisaran normal. Menurut Elpawati et al. (2015), kadar amonia dalam budidaya ikan lele dengan kisaran $<1 \mathrm{mg} / \mathrm{l}$ masih berada diatas batas optimum untuk pertumbuhan ikan lele.

\section{Kesimpulan dan Saran}

Penggunaan tepung lemna terfermentasi pada pakan buatan ikan lele dumbo (C. gariepinus) memberikan pengaruh yang nyata terhadap total konsumsi pakan (TKP), efisiensi pemanfaatan pakan (EPP), protein efisiensi rasio (PER) dan laju pertumbuhan relatif (RGR), namun tidak memberikan pengaruh yang nyata terhadap kelulushidupan (SR).

Dosis tertinggi yaitu pada dosis $20 \%$ dari penggunaan tepung lemna terfermentasi menghasilkan nilai total

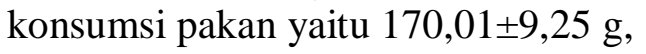
efsiensi pemanfaatan pakan (EPP) sebesar 78,82 $\pm 4,75 \%$, efesiensi protein rasio (PER) sebesar
$2,49 \pm 0,15 \%$ dan laju pertumbuhan relatif (RGR) sebesar $4,60 \pm 0,31 \% /$ hari.

Dosis optimum dari penggunaan tepung lemna terfermentasi terhadap total konsumsi pakan (TKP), efsiensi pemanfaatan pakan (EPP), efesiensi protein rasio (PER) dan laju pertumbuhan relatif (RGR) belum ditemukan titik optimumnya karena berdasarkan uji analisis ragam polinomial ortogonal didapatkan pola linier.

Saran yang dapat diberikan pada penelitian ini adalah perlu dilakukan penelitian lanjutan dengan menggunakan dosis lebih dari $20 \%$ penggunaan tepung lemna terefrmentasi pada pakan ikan lele dumbo.

\section{Ucapan Terima Kasih}

Terima kasih penulis ucapkan kepada kepala Balai Benih Ikan (BBI) Siwarak, Semarang yang telah menyediakan tempat dan fasilitas untuk pelaksanaan penelitian ini.

\section{Daftar Pustaka}

Abidin, Z., M. Junaidi, Paryono, N. Cokrowati, dan S. Yuniarti. 2015. Pertumbuhan dan Konsumsi Pakan Ikan Lele (Clarias sp.) yang Diberi Pakan Berbahan Baku Lokal. Depik 4(1): 33 - 39.

Arief, M., N. Fitriani dan S. Subekti.2014. Pengaruh Pemberian Probiotik Berbeda pada Pakan Komersial terhadap Pertumbuhan dan Efisiensi Pakan Ikan Lele Sangkuriang (Clarias sp.). Jurnal Ilmiah Perikanan dan Kelautan 6(1): 49 - 53. 
Arifin, Z., C. Kokarkin. dan T.P. Priyoutomo. 2007. Penerapan Best Management Practices pada Budidaya udang Windu (Panaeus monodon, Fabricus) Intensif. Direktorat Jendral Perikanan Budidaya, Jepara.

Crismadha, $\quad$ T. 2015. http://lipi.go.id/berita/lemnatumbuhan-air-limbah-yang-bisajadi-alternatif-pakan-ternak/10747

De Silva, S.S. 1987. Finfish Nutritional Research in Asia. Proceeding of The Second Asian Fish Nutrition Network Meeting. Heinemann, Singapore.

Dewanji A. 1993. Amino Acid Composition of Leaf Protein Extracted from Some Aquatic Weeds. J. Agric. Food Chem. 41: 1232-1236.

Effendie, M.I. 1997. Biologi Perikanan. Yayasan Pustaka Nusantara, Yogyakarta.

Ekasari, J. 2009. Teknologi Biotlok: Teori dan Aplikasi dalam Perikanan Budidaya Sistem Intensif. Jumal Akuakultur Indonesia 8(2): 117-126.

Elpawati, D.R. Pratiwi, dan N. Radiastuti. 2015. Aplikasi Efective Microoganism 10 (EM $\left.\mathrm{EM}_{10}\right)$ untuk Pertumbuhan Ikan Lele Sangkuriang (Clarias gariepinus var. Sangkuriang) di Kolam Budidaya Lele Jombang, Tangerang. Al-Kauniyah Jurnal Biologi 8(1): 6-14.

Fadri1, S., Z. A. Muchlisin, dan S. Sugito. 2016. Pertumbuhan, Kelangsungan Hidup dan Daya Cerna Pakan Ikan Nila (Oreochromis niloticus) yang Mengandung Tepung Daun Jaloh (Salix Tetrasperma Roxb) dengan Penambahan Probiotik EM-4.
Jurnal Ilmiah Mahasiswa Kelautan dan Perikanan Unsyiah 1(2) :210-221.

Francis, G., Makkar, H.P.S. and Becker, K. 2001. Antinutritional Factors Present in Plant-derived Alternate Fish Feed Ingredients and their Effects in Fish. Aquaculture 199: 197-227.

Hanafiah, K., A. 2000. Rancangan Percobaan Teori dan aplikasi. PT Raja Grafindo Persada, Jakarta.

Ilyas, A.P. 2014. Evaluasi Pemanfaatan Fitoremediator Lemna perpusilla sebagai Pakan Kombinasi dalam Pemberian Pakan Ikan Nila (Oreochromis niloticus) pada Sistem Resirkulasi. Tesis. Institut Pertanian Bogor, Bogor.

[KKP]. 2013. Laporan Tahunan Direktorat Produksi Tahun 2013. http://www.djpb.kkp.go.id/public/ upload/download/Pustaka/06PUS TAKA/LAPTAH\%20PRODUKSI \%20\%202013.pdf.

Madinawati , N.S., dan Yoel. 2011. Pemberian Pakan yang Berbeda terhadap Pertumbuhan dan Kelangsungan Hidup Benih Ikan Lele Dumbo (Clarias gariepinus). Media Litbang Sulteng 4(2): 83 87.

Martudi1, S. dan Lilisti. 2011. Analisis Pemberian Pakan dengan Kadar Protein yang Berbeda terhadap Pertumbuhan Ikan Lele Sangkuriang (Clarias sp). Jurnal Agroqua 9(1): 1-5.

Mohapatra, S.B. dan A.K.Patra. 2013. Effect of Partial Replacement of Fishmeal with Duck Weed (Lemna minor) Feed On the Growth Performance of Cyprinus carpio Fry. Journal of Agriculture and Veterinary Science 4(2): 34-37. 
Noviana, P., Subandiyono, dan Pinandoyo. 2014. Pengaruh Pemberian Probiotik dalam Pakan Buatan terhadap Tingkat Konsumsi Pakan dan Pertumbuhan Benih Ikan Nila (Oreochromis niloticus). Journal of Aquaculture Management and Technology 3(4): $183-190$.

Pamungkas, W. 2013. Uji Palatabilitas Tepung Bungkil Kelapa Sawit yang Dihidrolisis dengan Enzim Rumen dan Efek terhadap Respon Pertumbuhan Benih Ikan Patin Siam (Pangasius hypophthalmus Sauvage). Berita Biologi 12(3): 359 - 366.

Patra, A.K. 2015. Evaluation of the Duckweed (Lemnaminor) Meal as Partial Replacement for Fish Meal on the Growth Performance of Labeorohita (Ham.) fry. European Journal of Experimental Biology 5(10): $18-23$.

Pereira, L., Riquelme, T., dan Hosokawa, H. 2007. Effect of There Photoperiod Regimes on the Growth and Mortality of the Japanese Abalone (Haliotis discus hanaino). Skripsi. Kochi University, Aquaculture Department, Laboratory of Fish Nutrition, Japan.

Pomeroy, R.S., Parks, J.E., dan Balboa, C.M. 2006. Farming the Reef: is Aquaculture a Solution for Reducing Fishing Pressure on Coral Reef. Marine Policy 30:111130.

Rahmawan, H., Subandiyono, dan. Arini, E. 2014. Pengaruh Penambahan Ekstrak Pepaya dan Ekstrak NanasTerhadap Tingkat Pemanfaatan Protein Pakan dan Pertumbuhan Lobster Air Tawar (Cherax Quadricarinatus). J. Of
Aquaculture Management and Technology 3 (4): 75-83.

Revi, N.Y., Basri, dan Elfrida. 2013. Evaluasi Penggunaan Pakan Berbasis Bahan Baku Lokal terhadap Nilai Nutrien pada Ikan Nila (O. niloticus). J.Perikanan dan Kelautan 2(1): 1-9.

[SNI] 01- 6484.2 - 2000. Benih Ikan Lele Dumbo (Clarias gariepinus $x$ C.fuscus) Kelas Benih Sebar. BSN, Jakarta.

Sogbesan, O.A, Onoja, C.F., Adedeji, H.A., dan Idowu, T.A. 2015. Utilization of Treated Duckweed Meal (Lemna pausicostata) as Plant Protein Supplement in African Mud Catfish (Clarias gariepinus) Juvenile Diets. Fisheries and Aquaculture Journal 6(4): $1-5$.

Steel, R.G.D., dan Torrie, J.H. 1989. Prinsip dan Prosedur Statistika. Gramedia Pustaka, Jakarta.

Sulawesty, F., Chrismadha, T., dan Mulyana, E. 2014. Laju Pertumbuhan Ikan Mas (Cyprinus carpio L) dengan Pemberian Pakan Lemna (Lemna perpusilla Torr.) Segar pada Kolam Sistem Aliran Tertutup. Jurnal Limnotek 21 (2):177-184.

Tacon, A.E.J. 1987. The Nutrition and Feeding Formed Fish and Shrimp. a Training Manual Food and Agriculture. United Nation, Brazil.

Trisnawati, Y., Suminto, dan Sudaryono, A. 2014. Pengaruh Kombinasi pakan buatan dan Cacing Tanah (Lumbricus rubellus) terhadap Efisiensi Pemanfaatan Pakan, Pertumbuhan dan Kelulushidupan Lele Dumbo (Clarias gariepinus). Journal of 
Aquaculture Management and Technology 3(2): 86 - 93.

Warasto, Yulisman, dan Fitrani, M. 2013. Tepung Kiambang (Salvinia molesta) Terfermentasi sebagai

Bahan Pakan Ikan Nila (Oreochromis niloticus). Jurnal Akuakultur Rawa Indonesia 1(2): $173-183$.

Y1lmaz, E., Akyurt, I., dan Gunal, G. 2004. Use of Duckweed, Lemna minor, as a Protein Feedstuff in Practical Diets for Common Carp, Cyprinus carpio, Fry. Turkish Journal of Fisheries and Aquatic Sciences 4(1): 105-109.

Yuniwati, M., Iskarima, F., dan Padulemba, A. 2012. Optimasi Kondisi Proses Pembuatan Kompos dari Sampah Organik dengan cara Fermentasi Menggunakan EM4. Jurnal Teknologi 5(2): 172-181.

Yunus, T., Hasim, dan Tulyo, R. 2014. Pengaruh Padat Penebaran Berbeda terhadap Pertumbuhan Beih Ikan Lele Sangkuriang di Balai Benih Ikan Kota Gorontalo. Jurnal Ilmiah Perikanan dan Kelautan 2(3): 130 - 134.

Zahidah, Gunawan, W., dan Subhan, U. 2012. Pertumbuhan Populasi Daphnia sp. yang Diberi Pupuk Limbah Budidaya Karamba Jaring Apung (KJA) di Waduk Cirata yang Telah Difermentasi EM. Jurnal Akuatika 3(1):84 - 94. 
